\title{
A NEW ALIEN FISH IN THE MEDITERRANEAN SEA: CHAMPSODON NUDIVITTIS (ACTINOPTERYGII: PERCIFORMES: CHAMPSODONTIDAE)
}

\author{
Erdogan ÇIÇEK ${ }^{1}$ and Murat BILECENOGLU ${ }^{2 *}$ \\ ${ }^{1}$ Department of Biology, Faculty of Arts and Sciences, Nevsehir University, 50300 Nevsehir, Turkey \\ ${ }^{2}$ Department of Biology, Faculty of Arts and Sciences, Adnan Menderes University, 09010 Aydin, Turkey
}

Çiçek E., Bilecenoglu M. 2009. A new alien fish in the Mediterranean Sea: Champsodon nudivittis (Actinopterygii: Perciformes: Champsodontidae). Acta Ichthyol. Piscat. 39 (1): 67-69.

\begin{abstract}
A single specimen of nakedband gaper, Champsodon nudivittis (Ogilby, 1895), indigenous to the Indo West Pacific, was captured on 18 January 2008 from the Iskenderun Bay, Turkey. This is the first record of this species in the Mediterranean Sea. The most likely way of introduction would be via ships' ballast waters.
\end{abstract}

Keywords: Champsodon nudivittis, Champsodontidae, Mediterranean Sea, alien organism

Champsodontidae, commonly know as gapers, is a family of small sized fishes, characterized by having an elongated body covered with small, rough, non-overlapping denticulate scales, a large oblique mouth with at least two rows of teeth, a posteroventrally located preopercular spine, and a complex acoustico-lateralis system consisting of two lateral lines interconnected by vertical rows of sensory papillae (Nemeth 2001). The family members are poorly known biologically, where existing studies have concentrated on their taxonomy and phylogenetic relationships (i.e., Mooi and Johnson 1997). A comprehensive review recognized a single genus, Champsodon Günther, 1867, with 13 valid species confined to the IndoPacific region (Nemeth 1994).

On 18 January 2008, a single specimen (11.4 cm TL, $9.4 \mathrm{~cm} \mathrm{SL}$ ) of Champsodon nudivittis (Ogilby, 1895) was captured during a bottom trawl haul on board the $F / V$ COSKUN REIS, from a depth of $50 \mathrm{~m}$ in the outer part of Iskenderun Bay (Fig. 1). The specimen was fixed with 4\% formalin and deposited in the Zoology Museum of Adnan Menderes University (ZMADU). All measurements were taken with dial callipers to the nearest $0.1 \mathrm{~mm}$ following descriptions of Nemeth (1994) and counts were made under a stereomicroscope. In describing scale patterns, "chin" refers to the ventral region between the dentaries and "breast" refers to the triangular area anterior to the pelvic fin bases.

Description of the Mediterranean Sea specimen is as follows: first dorsal finrays IV, second dorsal finrays 20 , anal finrays 19, pectoral finrays 14 . First gill arch with one gill raker on upper limb and 10 on lower limb. Body elongate and slightly compressed laterally (Fig. 2A). Scales small and spinulose, with a conical support embedded in skin; bases of dorsal and anal fins scaleless; area between pectoral and pelvic fins naked, chin also naked but with distinct small melanophores; no scales on the belly as far as to anus (Fig. 2B); breast with small patch of scales. Mouth large and oblique; maxilla extending beyond posterior margin of eye; premaxilla with a distinct notch lateral to symphysis (Fig. 2C). A row of five pairs of sensory papillae (not arranged in semicircle) located between parallel bony ridges on dorsum of head, from snout to interorbital region. Lacrimal bone with two spines projecting anteroventrally; a characteristic posteroventral spine on the preopercle. Two horizontal lateral lines, comprising several small papillae. Pelvic fins much larger than pectorals; tip of longest pelvic finray not extending to anus. Head length 3.48, body depth (over anal fin origin) 5.53, body depth (over pelvic fin origin) 5.11, depth of caudal peduncle 15.67, predorsal length 3.36, preanal length 1.92, pelvic fin length 4.95 , all in SL; horizontal eye diameter 4.91, snout length 3.86 , pelvic fin length 1.42 , preopercular spine 6.75, all in head length. Snout 1.27 times the eye diameter; interorbital distance 1.22 in eye diameter; distance between spinous and soft dorsal fin origins 1.32 in predorsal length; least distance between eye and maxilla 0.55 times the eye. Colour of the preserved specimen is dark brown dorsally, light brown on the sides and pale at peritoneum. There are no conspicuous markings on the body, except for the dark blotch at caudal base and the small dark spotted area at chin. All morphometric measurements, meristic counts and colour description of the Mediterranean Sea specimen of $C$. nudivittis are well in accordance with Nemeth $(1994,2001)$.

\footnotetext{
* Correspondence: Dr. Murat Bilecenoğlu, Department of Biology, Faculty of Arts and Sciences, Adnan Menderes University, 09010 Aydin, Turkey, phone: +90-256-218-2000 ext. 2219, fax:+90-256-213-5379, e-mail: mbilecenoglu@adu.edu.tr or mbilecenoglu@yahoo.com
} 


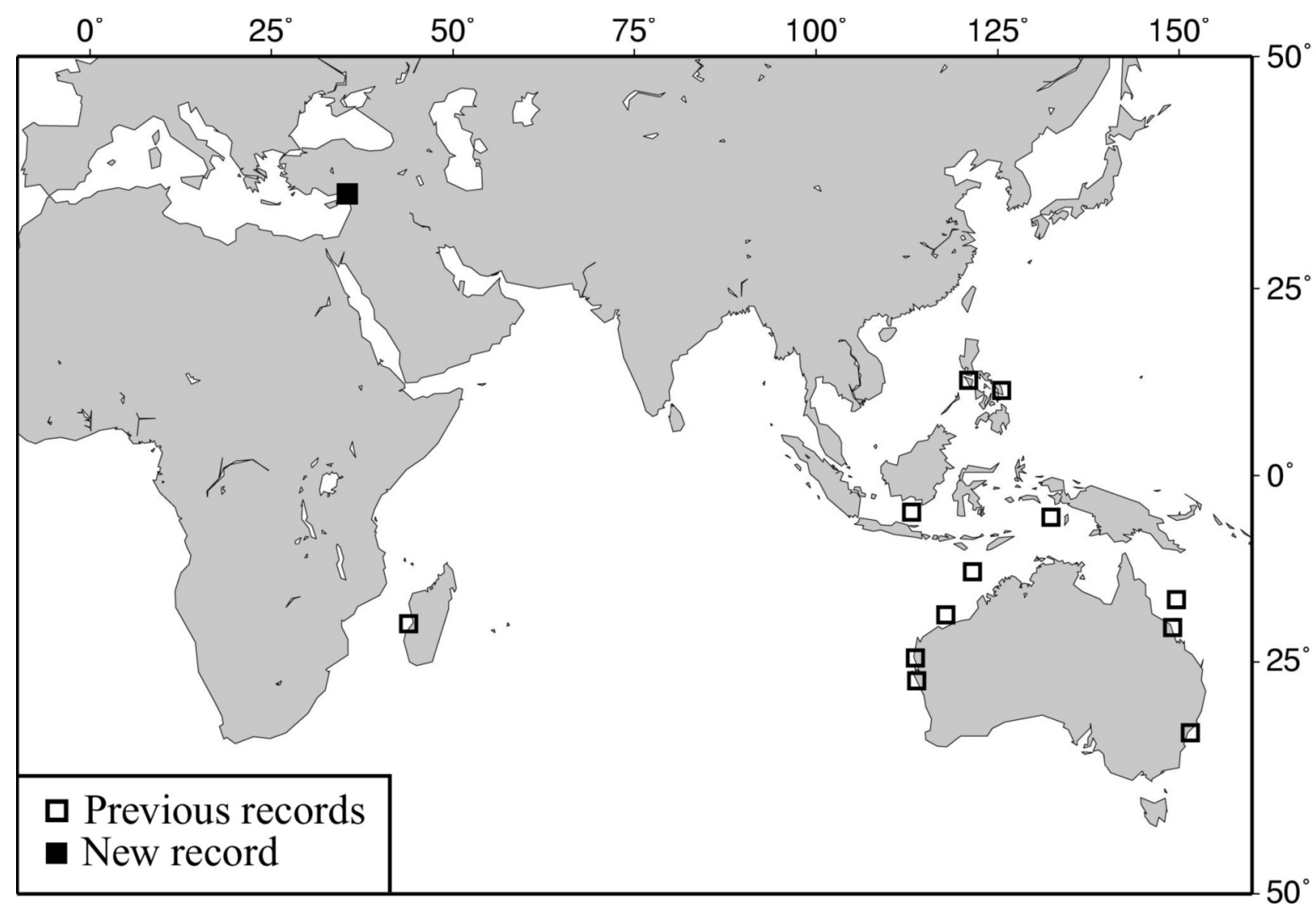

Fig. 1. Worldwide distribution map of Champsodon nudivittis (previous records from Nemeth 1994), including the new capture locality in the eastern Mediterranean Sea (Iskenderun Bay, Turkey)

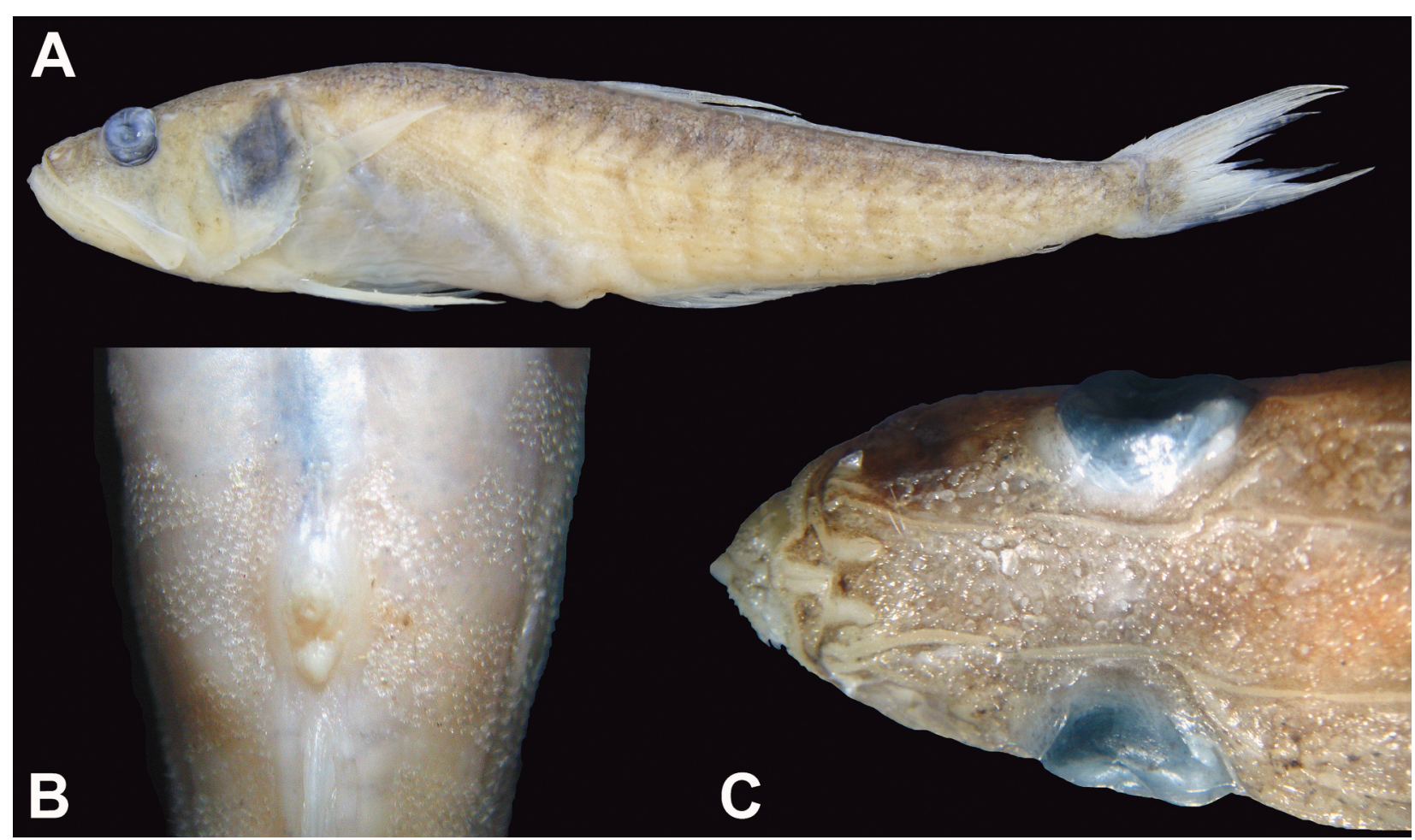

Fig. 2. The Mediterranean Sea specimen of Champsodon nudivittis: A general view, B scale pattern at the anal region, C dorsal view of head 
Distribution of $C$. nudivittis is confined to the Indo West Pacific Ocean, with records available from Australia, Indonesia, Madagascar, Papua New Guinea and Philippines (Nemeth 1994, Froese and Pauly 2008, Yearsley et al. 2006). There are no detailed information on the habitat of the species, but champsodontids were considered to be bottom dwellers due to their common occurrence in the trawl catches. Based on the high proportion of pelagic preys in stomach contents of some gapers, it is also suggested that they exhibit vertical migrations, moving upward at the night (Morohoshi and Sasaki 2003). The maximum capture depth of $C$. nudivittis is $335 \mathrm{~m}$ (Nemeth 1994).

Gapers are distinguished from each other by a combination of characters, which mainly include the scale pattern on various parts the body, arrangement and number of dorsal sensory papillae, degree of notching of the premaxillae and the gill raker counts on the first arch. Morphometric features are generally useless alone, due to great morphological similarity among the species. In terms of ventral scale pattern, C. nudivittis is most similar to C. guentheri Regan, 1908; C. machaeratus Nemeth, 1994; C. sagittus Nemeth, 1994; and C. snyderi Franz, 1910 , which can be distinguished from these species by having a small patch of scales on the breast (fully scaled in C. guentheri and C. snyderi, naked in C. machaeratus and C. sagittus) (Nemeth 1994).

Only two champsodontids were reported from the Red Sea to date (C. capensis Regan, 1908 and C. omanensis Regan, 1908) (Goren and Dor 1994). Considering the absence of $C$. nudivittis at both the north-western Indian Ocean and Red Sea, a natural range expansion of the species via Suez Canal does not seem to be reasonable (see Fig. 1). However, there is a gap of knowledge on Red Sea gapers; occurrence of $C$. capensis needs verification and $C$. nudivittis maybe a previously overlooked species in the region (M. Goren, pers. comm.). Based on currently available data, a ship-mediated introduction of the species from the Indo West Pacific to the Mediterranean Sea should be suspected.

\section{ACKNOWLEDGEMENTS}

We are grateful to captains Hakan Ozcan and Kasim Ozcan (F/V COSKUN REIS) for their help during the field works. Dr. Menachem Goren (Tel Aviv University) kindly confirmed species identification and sent information on gapers from Red Sea. We also acknowledge use of the Maptool program (www.seaturtle.org/maptool/).

\section{REFERENCES}

Froese R., Pauly D. (eds.) 2008. FishBase. http://www. fishbase.org.

Goren M., Dor M. 1994. An updated checklist of the fishes of the Red Sea. CLOFRESII. Jerusalem: The Israel Academy of Sciences and Humanities, Jerusalem.

Mooi R.D., Johnson G.D. 1997. Dismantling the Trachinoidei: evidence of a scorpaenoid relationship for the Champsodontidae. Ichthyological Research 44: 143-176. DOI: 10.1007/BF02678694.

Morohoshi U., Sasaki K. 2003. Intensive cannibalism and feeding on bregmacerotids in Champsodon snyderi (Champsodontidae): evidence for pelagic predation. Ichthyological Research 50: 387-390. DOI: 10.1007/ /s10228-003-0176-4.

Nemeth D. 1994. Systematics and distribution of fishes of the family Champsodontidae (Teleostei: Perciformes), with descriptions of three new species. Copeia 2: 347-371.

Nemeth D. 2001. Champsodontidae. Pp. 3497-3499. In: Carpenter K.E., Niem V.H. (eds.) FAO Species identification guide for fishery purposes. The living marine resources of the Western Central Pacific. Vol. 6. Bony fishes part 4 (Labridae to Latimeriidae), estuarine crocodiles, sea turtles, sea snakes and marine mammals, Rome, FAO.

Yearsley G.K., Last P.R., Hoese D.F. (eds.) 2006. Standard names of Australian fishes. CSIRO Marine and Atmospheric Research Paper 9: 1-65.

Received: 4 December 2008

Accepted: 30 March 2009

Published electronically: 20 May 2009 